\title{
Country Size and the Rule of Law: Resuscitating Montesquieu
}

\author{
Gustav Hansson and Ola Olsson* \\ Göteborg University
}

March 28, 2006

\begin{abstract}
The political and economic impact of country size has been a frequently discussed issue in social science. In accordance with the general hypothesis of Montesquieu, this paper demonstrates that there is a robust negative relationship between the size of country territory and a measure of the rule of law for a large cross-section of countries. We propose that there are two main reasons for this regularity; firstly that institutional quality often has the character of a local public good that is imperfectly spread across space from the capital to the hinterland, and secondly that a large territory usually is accompanied by valuable rents that tend to distort property rights institutions. Our empirical analysis further shows that whether the capital is centrally or peripherally located within the country matters for the average level of rule of law.

Keywords: country size, rule of law, institutions, development, Montesquieu.

JEL Codes: N40, N50, P33.

"It is in the nature of a republic that it should have a small territory; without that, it could scarcely exist. In a large republic, there are large fortunes, and consequently little moderation of spirit...

In a large republic, the common good is sacrificed to a thousand considerations; it is subordinated to various exceptions; it depends on accidents. In a small republic, the public good is more strongly felt, better known, and closer to each citizen..."

(From The Spirit of Laws, C.L. Montesquieu, 1750, Book VIII)
\end{abstract}

${ }^{*}$ Corresponding author: Ola Olsson, Department of Economics, Göteborg University, Box 640, 40530 Göteborg, Sweden. Email: ola.olsson@economics.gu.se. We are grateful for comments from Carl-Johan Dalgaard and seminar participants at Göteborg University. 


\section{Introduction}

We demonstrate that there is a robust negative relationship between the size of country territory and the strength of rule of law for a large cross-section of countries. We also show that the internal location of the capital matters for the geographical spreading of institutions. In the spirit of Montesquieu, we argue that there are two basic reasons for these results; firstly that large countries tend to be endowed with sizeable potential rents that distort the incentives of the regime, and secondly that the rule of law has the character of a local public good that is imperfectly broadcast from the country capital to the hinterland.

The importance of country size for social development has been a topic among political philosophers for centuries. Both Plato and Aristotle preceded Montesquieu arguing that small nations like the Greek city states were naturally superior to larger entities and that a country's entire territory should not be larger than that it could be surveyed from a hill. Likewise, Rousseau later claimed that small states prosper "...simply because they are small, because all their citizens know each other and keep an eye on each other, and because their rulers can see for themselves the harm that is being done and the good that is theirs to do..." (Rousseau, quoted in Rose, 2005).

The opposite argument, that the diversity of preferences and the effects of fractionalization are more easily handled within large countries, was proposed by both David Hume and James Madison. ${ }^{1}$ Later influential works like Dahl and Tufte (1973) and Alesina and Spolaore (2003) have tended to think of the problem as encompassing a trade-off where small countries have advantages in terms of democratic participation and preference homogeneity, whereas smallness on the other hand implies higher per capita costs of non-rival public goods, a small internal market, and that small countries easily might be partitioned or swallowed by larger countries with a greater military capacity. The latter argument appears to have been particularly relevant for the European continent (Tilly, 1990).

Within the economics discipline, the relationship between country size and economic performance has not rendered a lot of attention. Early endogenous growth models like Romer (1990) and Aghion and Howitt (1992)

\footnotetext{
${ }^{1}$ See Dahl and Tufte (1973), Alesina and Spolaore (2003), and Rose (2005) for reviews of the older literature.
} 
included a prediction that larger countries should grow faster because they had a larger pool of potential innovators. On the whole, these early models did not receive strong empirical support. ${ }^{2}$ Alesina et al (1998) show that large countries tend to have large governments and that they are less open to trade than smaller countries. Using the level of the population as the measure of country size, Rose (2005) fails to find any systematic effect of size on a range of institutional and economic performance variables. Dahl and Tufte (1973) is probably the most comprehensive study of the importance of country size and is one of few studies that actually considers country area as a potential determinant of economic outcomes.

A few articles focus on the endogenous determination of country size. In Friedman (1977), it is assumed that the size of tax revenues increases with country territory and that tax revenue-maximizing rulers therefore invest in extending their territory. In the end, this process will actually result in an equilibrium where rulers maximize their joint potential net revenue. In Alesina and Spolaore (1997, 2003), country size is endogenously determined as a result of a trade-off where large countries have economies of scale in public goods provision but a greater degree of preference heterogeneity. Wittman (2000) extends this framework by allowing for migration between countries in the spirit of Tiebout (1956).

The generality of the endogenous borders literature has been questioned by Herbst (2000). ${ }^{3}$ Although the endogenous borders literature is useful for understanding the European experience or developments over the very long run, it appears to have less to offer an analysis of politics in former colonies where borders were usually fixed by colonial powers and subsequently rarely changed. Indeed, Herbst argues that the exogenously given and more or less random configuration of borders in Africa must be a central feature in

\footnotetext{
${ }^{2}$ Kremer's (1993) extreme long-run analysis of population growth on different continents is sometimes viewed as giving some support to the 'scale-effect' prediction, but it was effectively refuted by the evidence in Jones (1995) and led to the development of growth models without scale effects.

${ }^{3}$ In Herbst's (2000, p 141) own words: "...the intertia of the national experience and the incentives posed by international structures and norms that have developed over time combine to make the demarcation of the state a non-issue in most countries most of the time. Here, I differ greatly from writings by economists who seek to find the optimal number of states by assuming that states cooperate to design themselves in a way that will maximize 'their joint potential net revenue' [Friedman] or who believe that the size and shape of states is determined on the basis of majority votes motivated by precise calculations of economic interests [Alesina and Spolaore]"
} 
comparative analyses of African politics.

In this article, we show that the size of country territory is negatively associated with a range of institutional measures such as rule of law, political stability, and corruption when using a sample of all countries in the world. We recognize however that boundaries are potentially endogenous and therefore restrict our analysis to former colonies whose borders were exogenously determined by the colonial powers. In a theoretical section, we argue that country size has two effects: Firstly, that a large territory means a larger absolute value of expected rents from lands and mines and that this stock of appropriable treasures makes self-interested autocratic rulers less interested in upholding strong private property rights and protection against expropriation. Secondly, that the strong concentration of power in the capitals of former colonies implies that public goods like the rule of law diffuse according to a spatial decay-function so that the levels felt in the hinterland are much weaker than in the capitals. This problem should be further exacerbated in countries where the capital is non-centrally located.

As the base sample for testing our hypotheses, we use data from 127 former colonies which - unlike most of the previous literature on colonialism - arguably contains all large and small countries that were ever colonized. We show that the size of country territory has a very robust negative impact on our measure of the rule of law, even after controlling for distance from the equator, openness to trade, settler mortality, ethnic fractionalization, colonial origin, continental dummies, and a number of other variables. We also show that country territory appears to have a stronger association with rule of law than the level of the population. This fact, together with the general endogeneity of population size to institutions, suggest to us that country territory is a more appropriate indicator of country size than population. Unlike any other study that we are aware of, we further construct two indicators of the peripherality of the capital. As hypothesized, it turns out that when we hold country territory and some other controls constant, the strength of rule of law decreases with our size-neutral measure of the peripherality of the capital. Our interpretation of these results is that exogenously determined country territory has been a major impediment to the creation of strong institutions in large countries like Indonesia, Sudan, and Algeria, whereas it has been highly beneficial to small countries like Bahrain, Martinique, and Singapore. 
Since the strength of rule of law is a kind of institutional variable, our approach is obviously highly related to the growing empirical literature on the determinants of institutional strength (Hall and Jones, 1999; Acemoglu et al, 2001, 2002; Rodrik et al, 2004). In the spirit of Glaeser et al (2004), we think of property rights institutions and the rule of law as a variable that governments actually can influence, at least in the medium run. In the theory section, an important assumption is that post-colonial regimes are capable and willing to undertake institutional change, although the impact of such policies depend on the colonial and pre-colonial institutional environment. This type of modelling therefore distinguishes our approach somewhat from works in the tradition of Douglass North such as Acemoglu et al $(2001,2002)$ where institutional persistence from colonial times is a central element.

The article is organized as follows: In section two, we give a general outline of the statistical correlations between country size and various indicators of institutional quality. In section three, we develop a theoretical framework for understanding the linkages between size and institutions. In section four, we provide the main empirical investigation using the reduced sample of former colonies. Section five concludes the exposition.

\section{Country Size and Institutions}

Country size is negatively associated with a range of measures of institutional quality. In Table 1, we use six different measures as dependent variables, capturing various types of institutions that are believed to be central for economic development. The six indicators are Rule of Law, Political Stability, Voice and Accountability, Government Effectiveness, Regulatory Quality, and Corruption for the year 2004, collected by Kaufmann et al (2005) (for a description of all variables, see the Data Appendix). As our measure of country size, we use LogArea, which shows the logged value of the total area of a country (including lakes and rivers) in square kilometers. The sample includes just above 200 countries, some of which are very small like Macau and Singapore.

As Table 1 shows, the coefficient for LogArea is negative and highly significant for all six dependent institutional variables. LogArea has its strongest impact on Rule of Law and Political Stability. In the latter case, $\log A$ - 
rea alone explains roughly 25 percent of the variation, which we think is a quite remarkable result but perhaps not surprising. It seems for instance natural that a large country is more likely to host rebel movements than small ones. However, the fit is substantially improved when we include Latitude, which measures absolute distance from the equator in latitude degrees, and a dummy for Neo-Europe which captures the influence of four outliers United States, Canada, Australia, and New Zealand. Especially the first three countries are anomalies in our investigation since they are very large countries far from the equator with good institutions. The dummy is highly significant in all columns, as is Latitude. Latitude is often included in empirical investigations of this kind and is believed to capture geographical, agricultural, and disease-related factors (Hall and Jones, 1999; Acemoglu et al, 2001; Olsson and Hibbs, 2005). Figure 1 shows the partial scatter plot between LogArea and Rule of law (controlling for Latitude and Neo-Europe).

The reduced form regressions in Table 1 show that country size seems to be strongly correlated with various types of institutional quality. However, the estimates do not tell us much about the causal mechanisms behind the results. Indeed, we suspect that the precise causal mechanism depends on what particular institutional variable we are considering. Therefore, we will henceforth focus more deeply on the variable that has attracted the greatest interest in the literature; Rule of law.

Another issue concerns the potential endogeneity of country size. In the theoretical model of Alesina and Spolaore (1997), country size is endogenously determined as a result of a trade-off between economies of scale in public goods provision and preference heterogeneity among the population. All else equal, large countries tend to have low costs per capita of public goods (like rule of law) but also people in the periphery who would prefer a different government policy. If this model is correct, then it would be inappropriate to include LogArea as an exogenous variable as in Table 1.

The generality of Alesina and Spolaore's view on country formation has been questioned by Herbst (2000). Although the type of process envisaged by Alesina and Spolaore probably has been in place in Europe and parts of Asia where country formation has been going on for centuries or even millennia, the same cannot be said of the former colonies in America and Africa that received independence much more recently. Herbst (2000) argues that for Africa in particular, the size and number of countries was organized 
in a more or less random manner during the infamous Berlin conference of 1885. First of all there was relatively little a priori information for boundary creators due to a lack of traditional boundaries as well as natural geographic boundaries. Ultimately, the Berlin conference made it possible to claim sovereignty over an area regardless of the ability to administer the area. Therefore, there was no discrimination enabling only the more powerful colonizers to claim large areas. The logic of the partition was primarily to serve European strategic interests and the colonial powers more or less ignored existing state structures and ethnic boundaries (Pakenham, 1991). Indeed, the wider effects of the random nature of African borders has been a major topic among Africanists (Davidson, 1992; Englebert et al, 2002). The endogeneity of borders can also be questioned for the other former colonies, although there are some examples of country break-ups after independence. ${ }^{5}$

The implication of the discussion above is that while it might be problematic to consider country size as fully exogenous in Europe and parts of Asia, this should not constitute a serious problem for former colonies. In the further theoretical and empirical analysis, we will therefore only consider the relationship between country size and rule of law in countries that were previously colonized.

\section{A Theoretical Framework}

In the model below, we aim to describe certain features of the political economy and institutional environment of a former colony with exogenous, randomly distributed borders instituted by the previous colonial power. ${ }^{6}$ The size of country territory is imagined to have two effects on the average level of rule of law: Firstly, a direct 'broadcasting-effect' that derives from many formal institutions' character of a local public good originating in the

\footnotetext{
${ }^{4}$ In Jackson and Rosberg's (1985, p 46) words: "The boundaries of many countries, particularly but by no means exclusively in French-speaking Africa, were arbitrarily drawn by the colonial powers and were not encouraging frameworks of unified, legitimate, and capable states."

${ }^{5}$ Well-known incidences of break-ups of colonies include the formation of India, Pakistan, and Bangladesh in 1949 and of Colombia, Venezuela, and Ecuador in 1830. However, all the countries mentioned had their break-up in conjunction with or very soon after independence and post-colonial developments have therefore had at most a very small impact on border formation.

${ }^{6}$ The model is not at all intended to capture the situation in the Neo-European former colonies. As in the empirical section, the historical trajectories of Australia, Canada, New Zealand, and the United States are anomalies to the theory below.
} 
country capital. Secondly, an indirect 'rent seeking-effect' such that larger countries tend to be endowed with a larger amount of primary sector rents, which in turn decreases government incentives towards maintaining strong property rights.

\subsection{The Broadcasting Effect}

We propose that rule of law has the basic character of a local public good that emanates from the capital of the country and where the effective level of the good declines with geographical distance from the capital. As noted above, we see a number of reasons for making this assumption.

Firstly, it is a very common assertion in the literature that both executive and legislative power in the newly independent colonies tended to originate almost exclusively from the capitals (Bates, 1981; Herbst, 2000). Following the old colonial logic, whoever controlled the capital was usually also internationally recognized as the legitimate regime. Given the lack of democracy and the non-existence of strong regional identities or federal states, the maintenance of rule of law remained highly centralized. ${ }^{7}$

Secondly, it is also often discussed how the 'broadcasting of power over space' in former colonies is associated with significant challenges, particularly in Africa (Herbst, 2000). Public goods like the legislation and enforcement of property rights were most strongly felt in and around the capital among the elite groups that controlled the state. In this sense, we argue that institutions tend to be local public goods in a similar sense as for instance knowledge production and $\mathrm{R} \& \mathrm{D}$.

Thirdly, even if the broadcasting of institutions had been smooth across geography, it is usually the case that the sympathy for the ruling elite and its laws decrease with distance from the capital. Alesina and Spolaore (1997) make a similar assumption but with the size of the population rather than geographical distance as the source of preference discordance. In any case, distance from the capital should be negatively associated with the strength of law enforcement and with the willingness of local people to comply with the rules endorsed by the elite in the capital.

In order to formalize this idea, let us imagine that the strength of rule of law in the capital of country $i$ is given by a variable $z_{i}$. Let us also

\footnotetext{
${ }^{7}$ There are of course exceptions to this generalization. India is a well-known example of a democratic country with strong regional autonomy.
} 
imagine, as in Alesina and Spolaore (1997), that the size and location of countries in the world can be described as non-overlapping intervals on the real line where $s_{i}>0$ is the size of country $i$ and where $\left[l_{i}, l_{i}+s_{i}\right] \subset \mathbb{R}_{+}$ defines the unique country location with $l_{i}>0$ as the 'coordinate' for the left-hand side border. $^{8}$ The capital of the country, in turn, is located at a point $c_{i} \in\left[l_{i}, l_{i}+s_{i}\right]$. Obviously, if the capital is located exactly in the middle of the country, it will be found at $c_{i}=l_{i}+s_{i} / 2$. The geographical distance from the capital to some location $l_{i, j} \in\left[l_{i}, l_{i}+s_{i}\right]$ within country $i$ is described by the term $d_{i, j}=\left|l_{i, j}-c_{i}\right| \in\left[0, s_{i}\right]$ (see Figure 2 for a graphical illustration).

A central assumption of our model is that the size distribution of former colonies was determined by a random, exogenous process. The former assumption is of course an important departure from the endogenous bordersmodels by Friedman (1977) and Alesina and Spolaore (1997) but is well in line with the literature on the history and political development of excolonies (Herbst, 2000; Englebert et al, 2002). We further make the implicit assumption that within countries, the population is randomly distributed across space.

As discussed above, we postulate that the strength of rule of law diminishes with distance from the capital according to a spatial decay-function

$$
z_{i, j}=z_{i}\left(1-a_{i} d_{i, j}\right)
$$

where $z_{i, j}$ is the level of rule of law at location $l_{i, j}$ and where $a_{i}>0$ is a parameter describing the marginal decline in institutional quality over space. The level of $a_{i}$ is assumed to be such that $a_{i} s_{i}<1 .^{9}$

If we define the average distance to the capital within a country as $\bar{d}_{i}$, we can calculate this measure as a weighted average

$$
\bar{d}_{i}=\frac{\left(c_{i}-l_{i}\right)^{2}+\left(l_{i}+s_{i}-c_{i}\right)^{2}}{2 s_{i}} .
$$

\footnotetext{
${ }^{8}$ The one-dimensional nature of country size is used for simplicity. As shown by Alesina and Spolaore (1997), modelling size as two-dimensional significantly increases the complexity of calculations without any intuitive gains.

${ }^{9}$ This condition is imposed to ensure that $z_{i, j}>0$ at all $l_{i, j}$. The same type of spatial decay-function for public goods is used by Arzaghi and Henderson (2005). 'Iceberg' functions in spatial economics and in the 'new economic geography' is discussed for instance by Krugman (1998).
} 
This distance function can assume two extreme values. The first is given by the situation when the capital is located exactly in the middle of the country so that $c_{i}=l_{i}+s_{i} / 2$. In this case, simple algebra shows that $\bar{d}_{i}=\frac{s_{i}}{4}$. In the other extreme case with the capital located at either of the two borders, we will have that $\bar{d}_{i}=\frac{s_{i}}{2}$. We can thus describe average distance more generally as

$$
\bar{d}_{i}=\frac{\left(1+q_{i}\right) s_{i}}{4}
$$

where $q_{i} \in[0,1]$ is a size-neutral index of the 'peripherality' of the capital where a high $q_{i}$ indicates a location near (or at) a border and where a low $q_{i}$ means a location near (or at) the center of the country.

\subsection{The Rent Seeking-Effect}

The level of institutional quality in the capital $z_{i}$ is to a large extent given by the colonial and pre-colonial history of the country, as argued by North (1990), Acemoglu et al (2001, 2002) and others. However, in the general spirit of Glaeser et al (2004) and the model in Congdon Fors and Olsson (2005), we argue that the institutional setup was partly also a choice variable for the post-colonial regimes.

In order to capture both of these features, we make a distinction between historical (pre-colonial and colonial) property rights institutions with an average strength of $x$ and endogenously determined current (post-colonial) institutions $z$. After independence, discontinuous breaks with the colonial regime were often made, which is the reason why we think of $x$ and $z$ as different variables. However, as will be shown, the choice of $z$ will partly depend on the historical level $x$.

We propose that autocratic post-colonial regimes typically faced a tradeoff between fostering strong or weak property rights institutions, i.e. a high or a low level of $z$. Strong property rights and a pervasive rule of law tended to favor the growth of a modern, export-oriented manufacturing sector that was dependent on highly mobile foreign investments and capital. However, a strong rule of law also served as a significant constraint on the regime and made rent extraction from a primary sector more difficult. ${ }^{10}$ The

\footnotetext{
${ }^{10}$ We recognize of course that all former colonies are not characterized by nondemocratic, self-interested rulers that maximize their own rents. However, we strongly believe that this generalization is more appropriate for this category of countries than it would be to include a benevolent social planner. Our model has some similarities to the
} 
primary sector in our model includes industries such as agriculture as well as various types of mineral extraction, including oil. The common feature of these economic activities is that they rely on a highly immobile factor of production (land and mines) and therefore tend to be less sensitive to the institutional environment in the country. ${ }^{11}$ Furthermore, there is generally a positive relationship between the magnitude of primary sector rents and the area of the country. ${ }^{12}$

We capture this reasoning formally by modelling a utility function for an autocratic ruling regime of the following appearance:

$$
U_{i}=m\left(x_{i}, z_{i}\right)+b_{i} r\left(x_{i}, z_{i}, s_{i}\right)
$$

The regime receives utility from private rents from manufacturing $m$ and from a primary sector $r . x_{i}$ measures the level of institutional quality given by colonial and pre-colonial history, whereas $z_{i}$ indicates the endogenously created institutions after independence. The parameter $b_{i}$ reflects the relative weight given to the primary sector in country $i$ for historical or for power strategic reasons not explained by the model. ${ }^{13}$

In line with the discussion above, we assume that $\frac{\partial m\left(x_{i}, z_{i}\right)}{\partial z_{i}}=m_{z}>0$ and that $\frac{\partial r\left(x_{i} z_{i}, s_{i}\right)}{\partial z_{i}}=r_{z}<0$. In order to understand the intuition behind the signs of these derivatives, consider the following example. Imagine that under the prevailing property rights institutions, a regime in some former colony captures rents by randomly expropriating 5 percent of firm revenues in the two sectors in the name of the state but for personal gain. Let us further assume that total revenues in each of the two sectors initially are 100 units so that rents are 5 units in each sector. An improvement in property rights institutions then occurs which manifests itself in a lowering of the

chapter in Alesina and Spolaore (2003) featuring the optimization problem of a dictatorial 'Leviathan'.

${ }^{11}$ The least sensitive type of natural resource production is probably low tech mining of for instance alluvial diamonds and gold. Such mining has often prevailed in Africa even during periods of a general institutional collapse (Olsson, 2005). It should be acknowledged that certain types of natural resource production - like oil drilling and off-shore diamond mining - typically involves advanced technology and a dependency on foreign capital, as in the manufacturing sector.

${ }^{12}$ Casual observation certainly suggests that large former colonies like the United States, Brazil, DR Congo, Angola, and Nigeria are well endowed with natural resources.

${ }^{13}$ In Congdon Fors and Olsson (2005), it was argued that $b_{i}$ gave an indication of the origins of the elite that came into power after independence. In many cases, this elite had very weak ties to the manufacturing sector and tended to favor the natural resource sectors. 
percentage of revenue expropriated in the two sectors from 5 to 4 percent. In the manufacturing sector, which relies on internationally mobile capital and investments, this good signal has a strong impact on total production that increases to 130 . The effective level of rents therefore actually increases to become 5.2 units. In the primary sector, with highly immobile investments, production increases but only by a relatively small amount to 110 units. Effective primary sector rents fall from 5 to 4.4 units. In this representative example, manufacturing rents thus turn out to have a positive relationship with the strength of property rights, whereas the reverse is true in the primary sector. ${ }^{14}$

We further make the implicit assumption that natural resources are distributed randomly over space, which implies that the absolute level of expected primary sector rents increases with the territory of the country. In order to avoid extra notation, we capture this idea by simply assuming $\frac{\partial r\left(x_{i}, z_{i}, s_{i}\right)}{\partial s_{i}}=r_{s}>0$. The same effect of space is not present in the manufacturing sector. All else equal, the utility of the regime thus always increases with territory. ${ }^{15}$ The logic of the model further suggests that the marginal utility of extra territory should decrease with the strength of the rule of law since rent appropriation by the elite is more difficult if private property rights are strong, implying $\frac{\partial^{2} r\left(x_{i}, z_{i}, s_{i}\right)}{\partial s_{i} \partial z_{i}}=r_{s z}<0$.

The historical experience given by $x_{i}$ shapes expectations about current behavior and exacerbates the marginal impact of a current institutional policy. In the numerical example above, the decrease in expropriation risk from 5 to 4 percent implied an increase in revenues with 30 units. In a country with favorable historical institutions, the reaction of an identical change in expropriation risk should be even greater, maybe increasing production to 150 and rents to 6 units. Likewise, production in the primary sector should be more responsive to a current institutional change, maybe increasing to 120 rather than to 110 . Rents would then be 4.8 rather than 4.4. In other words, a stronger institutional heritage means that the positive marginal effect of increasing $z_{i}$ increases with $x_{i}$ in the manufacturing

\footnotetext{
${ }^{14}$ Note, however, that a rational rent-maximizing regime (with $b_{i}=1$ ) would never choose to carry out this strengthening of institutions since the overall effect is a fall in rents from 10 to 9.6 units.

${ }^{15}$ If size had been a choice variable, all autocratic rulers in our model would thus have liked to increase the size of their country but would of course have been constrained by a similar desire among other dictatorial rulers, as in Friedman (1977).
} 
sector, whereas the negative marginal effect of increasing $z_{i}$ decreases with $x_{i}$ in the primary sector. Formally, this implies that $\frac{\partial^{2} m\left(x_{i}, z_{i}\right)}{\partial z_{i} \partial x_{i}}=m_{z x}>0$ and $\frac{\partial^{2} r\left(x_{i}, z_{i}, s_{i}\right)}{\partial z_{i} \partial x_{i}}=r_{z x}>0$.

A key feature of our model further concerns the relationship between $x_{i}$ and $s_{i}$. In line with the exogeneity of $s_{i}$ discussed above, we argue that $x_{i}$ had no impact on $s_{i}$, i.e. pre-colonial and colonial institutions did generally not affect the size distribution of countries. We recognize, however, that there could be a causal link from $s_{i}$ to $x_{i}$ such that the configuration of colonial institutions in the capital depended on the total size of colonial territory. It is not clear though what direction this influence would take among colonialists of different identity and in general we believe that the colonial rulers mainly cared about the situation in or near the capital.

Unlike in the framework of Alesina and Spolaore (1997), the choice variable in our model is the quality of a public good like the rule of law rather than country size. Another difference is that we do not believe that it is natural to assume economies of scale in public goods provision when area is the measure of country size. For simplicity, we also abstract from the costs of institutional change. ${ }^{16}$ The only constraint facing the regime is that the rule of law must not fall below a certain reservation level $z^{\text {min }}$. If it does, the people will overthrow the incumbent.

The ruling regime thus faces an optimization problem

$$
\max _{z_{i}} m\left(x_{i}, z_{i}\right)+b_{i} r\left(x_{i}, z_{i}, s_{i}\right) \quad \text { subject to } z_{i} \geq z^{\min } .
$$

If we disregard the possibility of a boundary solution, the (interior) equilibrium level of rule of law or property rights institutions $z_{i}^{*}$ is implicitly given by the first-order condition $m_{z}+b_{i} r_{z}=0$. In order to have an interior solution, it is further required that the second-order condition for maximum $m_{z z}+b_{i} r_{z z}<0$ is satisfied. Straightforward implicit differentiation then shows that

$$
\frac{\partial z_{i}^{*}}{\partial s_{i}}=\frac{-b_{i} r_{z s}}{m_{z z}+b_{i} r_{z z}} .
$$

Since we have already established that the denominator must be negative, it will be the case that $\frac{\partial z_{i}^{*}}{\partial s_{i}}<0$. We argue that this type of indirect negative

\footnotetext{
${ }^{16}$ The cost of institutional change is explicitly modelled in Congdon Fors and Olsson (2005). Naturally, costs of institutional change would imply that there is a bias toward keeping the institutions inherited from colonial days.
} 
relationship between institutional quality and territorial size is similar in spirit to what Montesquieu had in mind. We can also easily see that $\frac{\partial z_{i}^{*}}{\partial b_{i}}=$ $\frac{-r_{z}}{m_{z z}+b_{i} r_{z z}}<0$ and that $\frac{\partial z_{i}^{*}}{\partial x_{i}}=\frac{-m_{z x}-b_{i} r_{z x}}{m_{z z}+b_{i} r_{z z}}>0$. These results might be summarized by writing $z_{i}^{*}\left(x_{i}, b_{i}, s_{i}\right)$.

The equations above imply that the average strength of rule of law in a country $i$ will be given by: ${ }^{17}$

$$
\bar{z}_{i}=z_{i}^{*}\left(x_{i}, b_{i}, s_{i}\right) \cdot\left(1-\frac{a_{i}\left(1+q_{i}\right) s_{i}}{4}\right)
$$

The central insight from this expression is that rule of law will diminish with country size via two potential channels. The first direct 'broadcastingeffect' comes about due to the imperfect enforcement of institutions over space. This effect can however be mitigated by a low marginal decline of institutional quality $a_{i}$ and by a centrally placed capital (a low $q_{i}$ ). The second indirect 'rent seeking-effect' works via the level of primary sector rents that increases with country size and that tend to corrupt governmental institutional policy. The level of institutions will further be lower if the regime considers primary sector rents to be particularly valuable so that $b_{i}$ is high. Given all other variables, we also have institutional persistence such that current average institutional strength increases with past institutions $x_{i}$, as in much of the existing literature. Equation (6) will form the basis for the further empirical investigation in the next section.

\section{Empirical Analysis}

\subsection{Data and empirical specification}

Due to the potential endogeneity of country size, we use a restricted sample of 127 former colonies - colonized between 1462 and 1922 following the expansion of Western Europe - that we have identified among the 208 countries listed in Kaufmann et al (2005). Borders in former colonies have rarely been changed since colonial days and might reasonably be regarded as an exogenous variable in economic development. Some of the countries in our sample are very small both in terms of population and territory (for instance Nauru

\footnotetext{
${ }^{17}$ We might equivalently think of the expression in (6) as showing the expected quality of institutions for a randomly chosen individual (since individuals are randomly distributed across space).
} 
with a population of roughly 12,000 individuals on 21 square kilometers) and some are still dependencies to their old colonial powers. Many cross-country studies exclude such tiny countries, but given the issue at hand, they are relevant observations in our study. ${ }^{18}$ Our sample is by far the largest sample of former colonies in the literature and arguably includes all countries that were ever colonized.

The basic equation that we test in this section with many variations is given in $(7)$

$$
Z_{i}=\alpha_{0}+\alpha_{1} S_{i}+\alpha_{2} Q_{i}+C_{i}^{\prime} \alpha_{3}+\epsilon_{i}
$$

where $Z_{i}$ is the measure of Rule of law in country $i, S_{i}$ is our country size variable (mainly LogArea), $Q_{i}$ is our measure of the peripherality of the capital in the country, $C_{i}^{\prime}$ is a vector of control variables, $\epsilon_{i}$ is the normally distributed error term, and $\alpha_{k}$ (with $k=\{0,1,2,3\}$ ) are the estimated coefficients.

The main variable of interest here is of course $S_{i}$. We do not believe that it is practically possible to disentangle empirically a direct and an indirect effect of country size as in eq. (6) and we therefore only specify a reducedform relationship in (7). Our hypothesis is obviously that $\alpha_{1}<0$. The peripherality measure $Q_{i}$ is our equivalent of $q_{i}$ in (6). We are not aware of any other study that has tried to measure or estimate the impact of the peripherality of the capital on institutions or indeed on any other economic variable. We expect to find that $\alpha_{2}<0$. The control variables in $C_{i}^{\prime}$ will always include Latitude and Neo-Europe as in Table 1, but also a number of other variables suggested in the literature. The motivation for including Latitude is partially that it can be regarded as a proxy for the marginal 'spatial cost' of broadcasting institutions, $a_{i} \cdot{ }^{19} \mathrm{~A}$ Neo-Europe-dummy is included since these four countries are extreme outliers and do not fit well into our basic framework. We will also include various proxies for colonial institutions $x_{i}$ such that Acemoglu et al's (2001) Settler Mortality-variable, although this reduces our number of observations by almost one half. Lastly, $b_{i}$ will be considered as a deep parameter that we do not attempt to control

\footnotetext{
${ }^{18}$ In section 4.4 , we show that our main results are robust when we control for dependencies and exclude the smallest countries as well as those with the most uncertain data.

${ }^{19}$ See Diamond (1997), Herbst (2000), and Olsson and Hibbs (2005) for general treatments and Sachs (2001) for a more detailed discussion of the economic and institutional difficulties that are faced by governments near the equator.
} 
for.

\subsection{The Size Variable}

Before we carry out our basic task of estimating (7), we will make a digression on what country size variable $S_{i}$ that should be included. In the tradition of Alesina and Spolaore (1997, 2003) most studies have used the level of the population as the indicator of country size. In a recent paper, Rose (2005) investigates whether the level of the population has an impact on a battery of economic and institutional variables and finds that it has no or, at best, a very weak effect. We argue that unlike country area, the level of the population is in general endogenous to economic and institutional environments, sometimes even in the short run. ${ }^{20}$ Nonetheless, we include the level of the population as a regressor in Table 2 to check whether country area or population size can best explain variations in the rule of law.

To begin with, column (1) shows that LogArea is still a very strong predictor of Rule of law even in this sample, and together with the two primary controls (with unreported but highly significant estimates as in Table 1), it explains nearly 54 percent of the variation in the dependent variable (see Figure 3 for a partial scatter plot). If we were to interpret these results, a 100 percent increase in total area for any country would imply a reduction in the Rule of Law-index by 0.169 points, which translates into about 3.9 percent of the whole dispersion between the highest possible score and the lowest possible score. This relatively small effect is explained by that countries differ drastically in size. ${ }^{21}$ If we instead compare a country with a total area of 1,000 square kilometers (about the size of Hong Kong) with a country with an area of 1,000,000 square kilometers (like Mauretania or Bolivia), the model predicts that all else equal the larger country should have a score on Rule of law that is 1.17 points lower, which is clearly a large effect.

Column (2) shows that LogPop (the natural logarithm of the level of the

\footnotetext{
${ }^{20}$ There are several recent examples of episodes when the population has changed drastically as a result of institutional failures. In 1994, 800,000 Tutsi were slaughtered in Rwanda as a result of a collapse of the rule of law. The older experiences of Nazi Germany and Stalin's Soviet Union are well-known examples of how bad institutions have a very large impact on the level of the population.

${ }^{21}$ India, one of the largest countries in our sample, is about $130 ' 000$ times larger than Macau, which is one of the smallest countries in our sample.
} 
population) is also negative and significant when included alone, but its explanatory power is much lower. ${ }^{22}$ When included together with LogArea in column (5), LogPop is insignificant and changes sign whereas LogArea has almost exactly the same coefficient as before. Given the high correlation between LogArea and LogPop, one should of course not take the specific estimate seriously, but column (5) appears to indicate that even when holding population constant, Rule of law diminishes with country territory and retains its significance.

Table 2 also includes two other variables that are believed to be strongly associated with country size; population density in logs (LogPopDens) and a measure of the country's degree of openness (LogOpen) where the latter is measured in the conventional way as imports plus exports as a share of GDP. ${ }^{23}$ One might expect that a public good like the rule of law is more efficiently spread in a country with a high average population density in its territory. Column (3) confirms that LogPopDens is positively related to Rule of law. Of course, since population density is calculated as total population divided by total area, it does not make sense to run LogPopDens against LogArea.

A third variable that is highly related to country size is Openness. As Alesina et al (1998) and others have argued, small countries are naturally more open than larger countries that have major internal markets. In accordance with what is usually hypothesized in the literature, Table 2 suggests that a high degree of openness appears to act as a disciplining device for countries to uphold strong property rights and judicial constraints against opportunistic behavior by governments and individuals. The estimate in column (4) is positive and highly significant and the estimate is still significant when LogArea is included in column (6). This does not much affect the negative estimate for LogArea.

Lastly, in column (7) we consider the idea that territorial size might actually in part determine the level of the population. In a two-stage procedure, we first run a regression with $\log P$ op as the dependent variable and LogArea as the regressor. We then use the residuals from this estimation as

\footnotetext{
${ }^{22}$ This result stands in sharp contrast to the main tendency in Rose (2005) who finds no robust association between population size and a number of institutional and economic variables.

${ }^{23}$ See for instance Dahl and Tufte (1973) for an insightful discussion of how population density and openness to trade are related to country area and total population.
} 
the independent variable and Rule of law as the dependent one. We thus exploit the variation in the level of the population that is not explained by country area. The estimate for LogPop in column (7) is then negative but non-significant.

The main conclusion from Table 2 is that LogArea is the superior predictor of Rule of Law among the size-related measures. We recognize however that the chain of causality might partially run through LogPop, LogPopDens, and Openness to institutional quality. In the remaining estimations, we will run regressions where we do not include the other three size indicators but where the reasoning above should be kept in mind.

\subsection{The Centrality of the Capital}

Apart from the size of country territory, the degree of peripherality of the capital $q_{i}$ is a key ingredient in our theory and in our empirical model. The model predicts that rule of law should decrease with $q_{i}$, holding country size $s_{i}$ constant. Hence, we also expect a negative sign of $\alpha_{2}$ in (7). Using data from CEPII (2006) and CIA (2005), we have constructed a measure of the distance in kilometers from the approximate center of the country to the city hosting the seat of the government (which is usually also the capital) ${ }^{24}$ The measure is available for 120 countries in our ex-colony sample. The countries with the greatest distances are not surprisingly the United States and Canada. The natural logarithm of this score makes up LogDistance, which is featured in Table 3. When run together with LogArea, LogDistance is negative and significant in column (1), and strongly significant in column (2) when featured alone. The distance measure is clearly correlated with country area (larger countries like Brazil and Indonesia will, ceteris paribus, have a greater absolute distance from center to capital), and the coefficient in column (2) where LogArea is excluded presumably picks up some of the effect of country size. Furthermore, LogDistance is clearly an imperfect proxy for $q_{i}$ in the theory section which is a size-neutral index of the peripherality of the capital.

We have therefore created a measure that, we believe, more clearly reflects the degree of peripherality. We have done so by dividing our calculated

\footnotetext{
${ }^{24}$ The measure was produced by translating data on locations in latitude and longitude degrees to distances in kilometers by employing the Great Circle Formula. See the Data Appendix for the exact details.
} 
distance from center to capital by an approximate measure of the distance from the center of the country to the border, where we approximate the shape of all countries to be congruent to a circle as is common in the trade literature (Head and Meyer, 2002) (see Data Appendix for the details). This size-adjusted measure Periphery shows countries like Namibia and Costa Rica as being among the very lowest scorers whereas the countries with the most peripheral capitals include Mozambique and Benin. Figure 4 illustrates the peripherality measure with respect to Namibia (with a score of 0.125 ) and Mozambique (1.77).

The model predicts that the strength of rule of law should increase with $q_{i}$ holding $s_{i}$ constant, and in column (3) we try to accomplish a similar scenario. As hypothesized, Periphery has a negative coefficient and is significant (column 3) as well as when featured alone (column 4), although these results are somewhat sensitive to the inclusion of Somalia. LogArea remains negative and highly significant throughout all specifications. The results in Table 3, column 3 predicts that when controlling for area, the country with the most uncentrally located capital should have a Rule of Law level that is 0.54 points lower (equivalent to 13 percent lower) than a country with a perfectly centrally located capital. In summary, we believe that Table 3 provides supporting evidence of the notion that the geographical peripherality of the capital should matter for the average intensity of public goods like the rule of law.

\subsection{Other determinants}

In Table 4, we extend our set of control variables in $C_{i}^{\prime}$ from just Latitude and Neo-Europe to include several other variables that have been suggested in the literature. Ethnic, cultural, and or religious fractionalization is an often argued cause for differences in institutional quality and civil conflict (see for example Alesina et al (2003), Easterly and Levine (1997), and Hibbs (1973)). Recently, partly due to the revived interest in the effects of fractionalization, Alesina et al (2003) and Fearon (2003) have created new measures for different aspects of fractionalization. The measures Ethnic fractionalization from Fearon (2003) (hereafter called Ethnicity1) and Ethnic and Religious fractionalization (hereafter called Ethnicity2 and Religion) both from Alesina et al (2003) are used as control variables in equation (7). As can be seen from Table 4, the coefficient for LogArea is still negative and statistically 
significant, while controlling for the fractionalization measures. The coefficients for Ethnicity1 and Ethnicity2 are both positive and insignificant, while the coefficient for Religion is positive and statistically significant. ${ }^{25}$ Before we leave the fractionalization measures, it is interesting to note that the correlations between LogArea and the three fractionalization measures are surprisingly low ${ }^{26}$. A large country, therefore, does not automatically imply a more fractionalized country.

Since we have a sample of former colonies, variables related to colonial heritage are obviously highly relevant. An often used variable is Acemoglu et al's $(2001,2002)$ famous proxy for settler mortality, constructed by using data on the mortality of soldiers and bishops in tropical diseases during colonial days. The hypothesis proposed by Acemoglu et al (2001) was that a high settler mortality and a subsequent low intensity of European settlement should have contributed to extractive, harmful colonial institutions that have persisted to this day, and vice versa. ${ }^{27}$ The basic data on settler mortality is only available for 69 former colonies, but when controlling for Log Settler Mortality in Column (4) the coefficient for LogArea is still negative and significant.

The other colonial variables are Duration of colonial rule (suggested by Grier, 1999, and Price, 2003), Years of independence from colonial rule, a dummy for the colonies that were Colonized after 1850 (mainly Africa), and Legal Origin (as suggested by La Porta et al, 1999). Controlling for these measures of colonial heritage does not alter the main results; the coefficient for LogArea is still negative and significant in all regressions.

Further variables related to geography and natural resource endowments are included in Table 5. Controlling for Island countries (defined as countries with no land border), Landlocked countries, and Dependency countries (countries that are not sovereign), does not alter the significance of the coefficient for LogArea. The negative relation between the size of nations and Rule of Law is therefore not driven by small islands or dependency countries. Column 4 also shows that the coefficient for LogArea is still negative and significant when including dummies for Sub-Saharan Africa and Latin America.

\footnotetext{
${ }^{25}$ A similar result was obtained by Alesina et al (2003).

${ }^{26}$ The Pearson correlation coefficients between LogArea and Ethnicity1, Ethnicity2, and Religion, are respectively; 0.1735, 0.4441, and -0.0920 .

${ }^{27}$ See Rodrik et al (2004) and Glaeser et al (2004) for further discussions of this work.
} 
Furthermore Table 5 shows that the negative relationship between LogArea and Rule of Law is also robust while controlling for natural resource abundance. Column 5 includes countries which are major Oil exporters as well as countries where Diamonds were discovered prior to 1989, and Column 6 controls for the ratio between energy and mineral depletion as a share of GNI.

Although not shown, it is important to note that in the regression results above, Neo-Europe and Latitude are included in every regression. The regressions above would also be robust to the inclusion LogOpenness.

\subsection{Further Robustness Tests}

The last three columns of Table 5 test the robustness of the relation between LogArea and Rule of Law even further. First of all, in column 7, all the countries with a population less than 500'000 are excluded from the regression, while at the same time controlling for Islands, Dependency, NeoEurope, and Latitude. But not even this hard test alters the significance of the coefficient for LogArea.

In Column 8, we test for the robustness of the relationship between LogArea and Rule of Law by considering potential measurement error in the dependent variable. Our Rule of Law measure from Kaufmann et al (2005) is a composite index based on several different independent sources. Therefore, attached to each country's score is also the estimate's standard error and how many sources that has been used for that particular estimate. For the Rule of Law 2004 estimate, the great majority of countries have a standard error of between 0.1 and 0.2 . A natural cut-off point would therefore preferably be to exclude those countries with a standard error larger than 0.2 . This turns out to be almost the same as excluding those countries with less than six independent sources ${ }^{28}$. As can be seen from Column 8, excluding countries with a standard error larger than 0.2, while also controlling for Islands, Dependency, Neo-Europe, and Latitude, the coefficient for LogArea is still negative and significant.

The last regression in Table 5 uses Expropriation Risk as dependent variable (see for example Acemoglu et al, 2001, and Osili and Paulson, 2004). Expropriation Risk has often been used in the literature as a proxy for the

\footnotetext{
${ }^{28}$ Excluding countries with a standard error larger than 0.2 also excludes Burundi and Eritrea, (compared to excluding countries with less than six sources).
} 
strength of property rights institutions in the same manner as Rule of law. The Expropriation Risk data is retrieved from Acemoglu et al (2001) and its usage reduces the sample size from 127 to 62 former colonies. However, neither the change in dependent variable, nor the drastic reduction in sample size alters the main result; the coefficient for LogArea is still negative and significant.

Furthermore, the estimated coefficient for LogArea in Table 2, column 1 , is not statistically different from any of the estimates coefficients from Table 4 or Table 5 . We believe that these results strongly indicate that the territorial size of nations is an important determinant of the rule of law and of institutional choice in general.

\section{Conclusions}

In the spirit of Montesquieu, this paper demonstrates that there is a clear, robust and significant negative relationship between the size of nations and the strength of rule of law for a large cross-section of countries. For former colonies, up to 60 percent of the variation in rule of law is explained by the variables LogArea, Latitude, and NeoEurope. This strong negative relationship is robust to the inclusion of a variety of control variables such as trade openness, ethnic and religious fractionalization, settler mortality, colonial heritage, and legal origin. The negative relation between LogArea and Rule of Law is even robust to including the level of the population, suggesting that country area is a stronger predictor of institutional quality than population levels. We believe that these results strongly suggest that large countries are seriously disadvantaged in the formation and maintenance of institutions for economic development.

In our model, we further propose that the centrality of the capital should play a vital role in the broadcasting of high quality institutions. We therefore construct a measure for the peripherality of the capital by relating the distance in kilometers from the capital to the approximative center of the country, to the distance from the center of the country to the border. As predicated by our model, the centrality of the capital indeed appears to be an important variable for explaining the variation in the Rule of Law. We believe that the relationship between the location of the capital and the country-wide provision of public goods is a potential area for future research. 


\section{References}

[1] Acemoglu, D., S. Johnson and J.A. Robinson (2000) "The Colonial Origins of Comparative Development: An Empirical Investigation" NBER Working Paper 7771, <http://www.nber.org/papers/w7771>

[2] Acemoglu, D., S. Johnson and J.A. Robinson (2001) "The Colonial Origins of Comparative Development: An Empirical Investigation" American Economic Review 91(5): 1369-1401.

[3] Acemoglu, D., S. Johnson and J.A. Robinson (2002) "Reversal of Fortune: Geography and Institutions in the Making of the Modern World Income Distribution", Quarterly Journal of Economics 117(4): 1231-1294.

[4] Aghion, P. and P. Howitt (1992) "A Model of Growth Through Creative Destruction", Econometrica 60(2), 323-351

[5] Alesina, A., Devleeschauwer, A., Easterly, W., Kurlat, S., and R. Wacziarg. (2003). "Fractionalization", Journal of Economic Growth. 8(2), 155-194.

[6] Alesina, A. and G. Spolaore (1997) "On the Number and Size of Nations" Quarterly Journal of Economics 112: 1027-1056.

[7] Alesina, A. and G. Spolaore (2003) The Size of Nations Cambridge, Mass: MIT Press.

[8] Alesina, A, G. Spolaore, and R. Wacziarg (1998) "Openness, Country Size, and Government" Journal of Public Economics 69: 305-321.

[9] Arzaghi, M. and V. Henderson (2005) "Why Countries Are Fiscally Decentralizing" Journal of Public Economics 89: 1157-1189.

[10] Bates, R.H. (1981) Markets and States in Tropical Africa: The Political Basis of Agricultural Policies, Berkeley: University of California Press.

[11] CEPII (2006) "Distances" < http://www.cepii.fr/anglaisgraph/bdd/distances.htm>.

[12] CIA (2005) The World Factbook 2005. <http://www.cia.gov/cia/ publications/factbook/index.html $>$, accessed nov-dec.

[13] Congdon Fors, H. and O. Olsson (2005) "Endogenous Institutional Change After Independence" Working Papers in Economics 163, Göteborg University.

[14] Dahl, R.A. and E.R. Tufte (1973) Size and Democracy. Stanford University Press. 
[15] Davidson, B. (1992) The Black Man's Burden: Africa and the Curse of the Nation-State, New York: Times Books.

[16] Diamond, J. (1997) Guns, Germs, and Steel: The Fates of Human Societies. London: W W Norton \& Company.

[17] Englebert, P., S. Tarango, and M. Carter (2002) "Dismemberment and Suffocation: A Contribution to the Debate on African Boundaries" Comparative Political Studies 35(10), 1093-1118.

[18] Easterly, W., and R. Levine. (1997) "Africa's Growth Tragedy: Policies and Ethnic Divisions" Quarterly Journal of Economics, Vol. 112, No. 4: 12031250.

[19] Fearon, J. (2003) "Ethnic and Cultural Diversity by Country" Journal of Economic Growth 8(2): 195-222.

[20] Friedman, D. (1977) "A Theory of the Size and Shape of Nations" Journal of Political Economy 85(1): 59-77.

[21] Glaeser, E., R. la Porta, F. Lopez-de-Silanes, and A. Shleifer (2004) "Do Institutions Cause Growth?" Journal of Economic Growth 9: 271-303.

[22] Grier, R. M., (1999), "Colonial legacies and economic growth", Public Choice Vol. 98:317-335.

[23] Hall, R. and C.I. Jones (1999) "Why Do Some Countries Produce So Much More Output Than Others?" Quarterly Journal of Economics 114(1): 83-116.

[24] Head, K. and T. Meyer (2002) "Illusory Border Effects: Distance Mismeasurement Inflates Estimates of Home Bias in Trade" CEPII Working paper, 2002-01, $<$ http://www.cepii.fr/anglaisgraph/workpap/summaries/2002/wp0201.htm $>$.

[25] Herbst, J. (2000) States and Power in Africa. Princeton University Press.

[26] Hibbs, D.A. (1973), Mass Political Violence, New York, Wiley

[27] Jackson, R.H. and C.G. Rosberg (1985) "The Marginality of African States", in Carter, G. and P. O'Meara, African Independence: The First Twenty Five Years. Bloomington: Indiana University Press.

[28] Jones, C. (1995) "R\&D-Based Models of Economic Growth", Journal of Political Economy 103(4), 759-784. 
[29] Kaufmann, D., A. Kraay, and M. Mastruzzi (2005) "Governance Matters IV: Governance Indicators for 1996-2004" World Bank Policy Research Working Paper 3630.

[30] Kremer, M. (1993) "Population Growth and Technological Change: One Million B.C. to 1990" Quarterly Journal of Economics 108(3): 681-716.

[31] Krugman, P. (1998) "Space: The Final Frontier" Journal of Economic Perspectives 12(2): 161-174.

[32] La Porta, R., Lopez-de-Silanes, F., Shleifer, A., and R. Vishny., (1999), "The Quality of Government", Journal of Law, Economics, Es Organization, V15, N1.

[33] Lujula, P., N.P. Gleditsch, and E. Gilmore (2005) "A Diamond Curse? Civil War and a Lootable Resource", Journal of Conflict Resolution 49(4): 538562 .

[34] Montesquieu, C.L. (1750) The Spirit of Laws. (Quoted in Dahl, R.A. and E.R. Tufte (1973), p 7).

[35] Olsson, O. (2005) "Diamonds Are A Rebel's Best Friend", forthcoming in The World Economy.

[36] Olsson, O. and D.A Hibbs (2005) "Biogeography and Long-Run Economic Development" European Economic Review 49(4): 909-938.

[37] Osili, U. O., and A. Paulson. (2004) "Institutional Quality and Financial Market Development: Evidence from International Migrants in the U.S." Federal Reserve Bank of Chicago WP 2004-19. $<$ http://www.chicagofed.org/publications/workingpapers/wp2004_19.pdf.>

[38] Pakenham, T. (1991) The Scramble for Africa. London: Abacus.

[39] Price, G. N., (2003), "Economic Growth in a Cross-section of Nonindustrial Countries: Does Colonial Heritage Matter for Africa?", Review of Development Economics, Vol. 7(3): 478-795.

[40] Rodrik, D., A. Subramanian and F. Trebbi (2004) "Institutions Rule: The Primacy of Institutions Over Geography and Integration in Economic Development" Journal of Economic Growth 9(2): 131-165.

[41] Romer, P. (1990) "Endogenous Technological Change", Journal of Political Economy 98(5), 71-102. 
[42] Rose, A.K. (2005) "Size Really Doesn't Matter: In Search of a National Scale Effect" CEPR Working Paper No 5350.

[43] Sachs, J. (2001) "Tropical Underdevelopment" NBER Working Paper 8119, NBER.

[44] Tiebout, C. (1956) "A Pure Theory of Local Expenditures" Journal of Political Economy 64: 416-424.

[45] Tilly, C. (1990) Coercion, Capital, and European States, AD 990-1992. Cambridge, Mass: Blackwell.

[46] Wittman, D. (2000) "The Wealth and Size of Nations" Journal of Conflict Resolution 44(6): 868-884. 
Table 1: Regressions for various measures of institutional quality in 2004.

\begin{tabular}{|c|c|c|c|c|c|c|c|c|c|c|c|c|}
\hline & \multicolumn{12}{|c|}{ Dependent variables } \\
\hline Independent variable & $\begin{array}{c}(1) \\
\text { Rule of } \\
\text { Law }\end{array}$ & $\begin{array}{c}(2) \\
\text { Rule of } \\
\text { Law }\end{array}$ & $\begin{array}{c}(3) \\
\text { Political } \\
\text { Stability } \\
\end{array}$ & $\begin{array}{c}(4) \\
\text { Political } \\
\text { Stability } \\
\end{array}$ & $\begin{array}{c}\text { (5) } \\
\text { Voice \& } \\
\text { Account }\end{array}$ & $\begin{array}{c}6) \\
\text { Voice \& } \\
\text { Account } \\
\end{array}$ & $\begin{array}{c}\text { (7) } \\
\text { Gov't } \\
\text { Effective }\end{array}$ & $\begin{array}{c}(8) \\
\text { Gov't } \\
\text { Effective }\end{array}$ & $\begin{array}{c}\text { (9) } \\
\text { Reg } \\
\text { Quality } \\
\end{array}$ & $\begin{array}{c}(10) \\
\text { Reg } \\
\text { Quality }\end{array}$ & $\begin{array}{c}(11) \\
\text { Corrup- } \\
\text { tion } \\
\end{array}$ & $\begin{array}{c}\text { (12) } \\
\text { Corrup- } \\
\text { tion } \\
\end{array}$ \\
\hline LogArea & $\begin{array}{l}-0.126^{* * *} \\
{[0.018]}\end{array}$ & $\begin{array}{l}-0.167^{* * *} \\
{[0.016]}\end{array}$ & $\begin{array}{l}-0.166^{* * *} \\
{[0.017]}\end{array}$ & $\begin{array}{l}-0.198^{* * *} \\
(0.018)\end{array}$ & $\begin{array}{l}-0.116^{* * *} \\
{[0.018]}\end{array}$ & $\begin{array}{l}-0.149^{* * *} \\
{[0.017]}\end{array}$ & $\begin{array}{l}-0.068^{* * *} \\
(0.022)\end{array}$ & $\begin{array}{l}-0.110^{* * *} \\
(0.019)\end{array}$ & $\begin{array}{l}-0.115^{* * *} \\
{[0.021]}\end{array}$ & $\begin{array}{l}-0.158^{* * *} \\
{[0.017]}\end{array}$ & $\begin{array}{l}-0.092^{* * *} \\
(0.024)\end{array}$ & $\begin{array}{l}-0.141^{* * *} \\
{[0.017]}\end{array}$ \\
\hline Latitude & & $\begin{array}{c}0.027^{* * *} \\
{[0.004]}\end{array}$ & & $\begin{array}{l}0.021^{* * *} \\
(0.003)\end{array}$ & & $\begin{array}{c}0.020^{* * *} \\
{[0.003]}\end{array}$ & & $\begin{array}{c}0.030^{* * *} \\
(0.003)\end{array}$ & & $\begin{array}{l}0.026^{* * *} \\
{[0.004]}\end{array}$ & & $\begin{array}{c}0.028^{* * *} \\
{[0.004]}\end{array}$ \\
\hline Neo-Europe & & $\begin{array}{c}2.063^{* * *} \\
{[0.217]}\end{array}$ & & $\begin{array}{l}1.547^{* * *} \\
(0.395)\end{array}$ & & $\begin{array}{c}1.683^{* * *} \\
{[0.192]}\end{array}$ & & $\begin{array}{l}1.949^{* * *} \\
(0.412)\end{array}$ & & $\begin{array}{c}1.798^{* * *} \\
{[0.208]}\end{array}$ & & $\begin{array}{c}2.206^{* * *} \\
{[0.207]}\end{array}$ \\
\hline$R^{2}$ & 0.145 & 0.444 & 0.251 & 0.428 & 0.123 & 0.305 & 0.043 & 0.377 & 0.108 & 0.363 & 0.069 & 0.397 \\
\hline$n$ & 208 & 208 & 207 & 207 & 207 & 207 & 209 & 209 & 204 & 204 & 204 & 204 \\
\hline
\end{tabular}

Notes: The superscript ${ }^{* * *}$ denotes significant at the $1 \%$ level, ${ }^{* *}$ significant at the $5 \%$ level, ${ }^{*}$ significant at the $10 \%$ level. Standard errors in ( ), robust standard errors in [ ]. Robust standard errors have been used when the null-hypotheses of no heteroscedasticity according to White's test could be rejected. Intercept included but not reported. Estimated by OLS. 
Table 2: Regressions for Rule of law in 2004 among former colonies using alternative measures of country size.

Dependent variable: Rule of law in 2004

\section{(1)}

(2)

(3)

(4)

(5)

(6)

$(7)^{\mathrm{a}}$

LogArea

$-0.169^{* * *}$

(0.018)

$\begin{array}{ll}-0.160^{* * *} & -0.117^{* * *} \\ {[0.044]} & (0.025)\end{array}$

LogPop

$-0.194^{* * *}$

(0.026)

$-0.015$

[0.057]

$-0.020$

(0.059)

$\begin{array}{cc} & 0.201^{* * *} \\ \text { LogPopDens } & (0.040)\end{array}$

LogOpen

$0.596^{* * *} \quad 0.263^{\text {** }}$

[0.128] (0.128)

Controls for Latitude and Neo-Europe

$\begin{array}{ccccccc}\text { Yes } & \text { Yes } & \text { Yes } & \text { Yes } & \text { Yes } & \text { Yes } & \text { Yes } \\ 0.536 & 0.455 & 0.346 & 0.455 & 0.536 & 0.562 & 0.214 \\ 127 & 127 & 127 & 97 & 127 & 97 & 127\end{array}$

$R^{2}$

127

127

127

Notes: The superscript ${ }^{* * *}$ denotes significant at the $1 \%$ level, ${ }^{* *}$ significant at the $5 \%$ level, ${ }^{*}$ significant at the $10 \%$ level. Standard errors in ( ), robust standard errors in [ ]. Robust standard errors have been used when the null-hypotheses of no heteroscedasticity according to White's test could be rejected. Intercept included but not reported. Estimated by OLS.

a: The component of LogPop orthogonal to LogArea is used instead of LogPop. 
Table 3: Testing for the centrality of the capital among former colonies.

Dependent variable: Rule of law in 2004

\begin{tabular}{|c|c|c|c|c|}
\hline Independent variables & (1) & (2) & $(3)^{\mathrm{a}}$ & $(4)^{\mathrm{a}}$ \\
\hline LogArea & $\begin{array}{l}-0.1162^{* * *} \\
(0.0297)\end{array}$ & & $\begin{array}{l}-0.1872^{* * *} \\
(0.0265)\end{array}$ & \\
\hline LogDistance & $\begin{array}{l}-0.1283^{* *} \\
(0.0602)\end{array}$ & $\begin{array}{l}-0.3023^{* * *} \\
(0.0429)\end{array}$ & & \\
\hline Periphery & & & $\begin{array}{l}-0.2504^{*} \\
(0.1473)\end{array}$ & $\begin{array}{l}-0.3222^{*} \\
(0.1822)\end{array}$ \\
\hline $\begin{array}{l}\text { Controls for Latitude and } \\
\text { Neo-Europe }\end{array}$ & Yes & Yes & Yes & Yes \\
\hline$R^{2}$ & 0.5270 & 0.4640 & 0.5221 & 0.2571 \\
\hline$n$ & 120 & 120 & 95 & 95 \\
\hline
\end{tabular}


Table 4: Controlling for Fractionalization and Colonial Heritage

Dependent variable: Rule of Law in 2004

\begin{tabular}{|c|c|c|c|c|c|c|c|c|}
\hline Independent variables & $(1)$ & $(2)$ & (3) & $(4)$ & $(5)$ & $(6)$ & (7) & $(8)^{b}$ \\
\hline LogArea & $\begin{array}{l}-0.1518^{* * *} \\
{[0.0454]}\end{array}$ & $\begin{array}{l}-0.1738^{* * *} \\
(0.0240)\end{array}$ & $\begin{array}{l}-0.1664^{* * *} \\
(0.0188)\end{array}$ & $\begin{array}{l}-0.1830^{* * *} \\
(0.0334)\end{array}$ & $\begin{array}{l}-0.1622^{* * *} \\
(0.0183)\end{array}$ & $\begin{array}{l}-0.1707^{* * *} \\
(0.0199)\end{array}$ & $\begin{array}{l}-0.1642^{* * *} \\
(0.0180)\end{array}$ & $\begin{array}{l}-0.1556 \\
(0.0191)\end{array}$ \\
\hline Ethnicity1 & $\begin{array}{c}0.2986 \\
{[0.2695]}\end{array}$ & & & & & & & \\
\hline Ethnicity2 & & $\begin{array}{c}0.0866 \\
(0.2621)\end{array}$ & & & & & & \\
\hline Religion & & & $\begin{array}{c}0.4032^{*} \\
(0.2391)\end{array}$ & & & & & \\
\hline Log Settler Mortality & & & & $\begin{array}{l}-0.2400^{* * *} \\
(0.0659)\end{array}$ & & & & \\
\hline Duration of colonial rule & & & & & $\begin{array}{l}0.0010^{* *(a)} \\
(0.0004)\end{array}$ & & & \\
\hline $\begin{array}{l}\text { Years of independence from colonial } \\
\text { rule }\end{array}$ & & & & & & $\begin{array}{c}0.0002 \\
(0.0011)\end{array}$ & & \\
\hline Colonized after 1850 (dummy) & & & & & & & $\begin{array}{l}-0.2944^{* * *} \\
(0.1090)\end{array}$ & \\
\hline Legal Origin UK (dummy) & & & & & & & & $\begin{array}{l}1.0949^{* * *} \\
(0.2115)\end{array}$ \\
\hline Legal Origin France (dummy) & & & & & & & & $\begin{array}{l}0.9181^{* * *} \\
(0.2467)\end{array}$ \\
\hline Legal Origin Socialist (dummy) & & & & & & & & $\begin{array}{c}0.2871 \\
(0.3654)\end{array}$ \\
\hline$R^{2}$ & 0.4776 & 0.5228 & 0.5463 & 0.6516 & 0.5544 & 0.5360 & 0.5621 & 0.6041 \\
\hline$n$ & 92 & 117 & 125 & 69 & 127 & 127 & 127 & 125 \\
\hline
\end{tabular}

Notes: All regressions include controls for neo-Europe and absolute latitude, all regressions except (8) also include a constant. The superscript ${ }^{* * *}$ denotes significant at the $1 \%$ level, ${ }^{* *}$ significant at the $5 \%$ level, ${ }^{*}$ significant at the $10 \%$ level. Standard errors in ( ), robust standard errors in [ ], Robust standard errors have been used when the null-

hypotheses of no heteroscedasticity according to White's test could be rejected (White, 1980). Intercept included but not reported. Estimated by OLS.

a) All estimates have been rounded, the more exact parameter estimate for this heading is 0.0009717 with a standard error of 0.0004313 which gives a p-value of 0.026

b) No intercept is included. 
Table 5: Geography and Natural Resources Controls

\begin{tabular}{|c|c|c|c|c|c|c|c|c|c|}
\hline & \multicolumn{8}{|c|}{ Dependent Variable: Rule of Law } & \multirow{2}{*}{$\begin{array}{c}\begin{array}{c}\text { Expropriation } \\
\text { Risk }\end{array} \\
(9)^{\mathrm{C}}\end{array}$} \\
\hline & $(1)$ & $(2)$ & (3) & $(4)$ & $(5)$ & (6) & $(7)^{\mathrm{a}}$ & $(8)^{b}$ & \\
\hline LogArea & $\begin{array}{c}-0.1548^{* * *} \\
(0.0263)\end{array}$ & $\begin{array}{c}-0.1631^{* * *} \\
(0.0186)\end{array}$ & $\begin{array}{c}-0.1525^{* * *} \\
(0.0191)\end{array}$ & $\begin{array}{l}-0.1551^{* * *} \\
(0.0184)\end{array}$ & $\begin{array}{l}-0.1768^{* * *} \\
(0.0216)\end{array}$ & $\begin{array}{l}-0.1537^{* * *} \\
(0.0206)\end{array}$ & $\begin{array}{l}-0.1115^{* * *} \\
{[0.0429]}\end{array}$ & $\begin{array}{l}-0.1179^{* * *} \\
(0.0398)\end{array}$ & $\begin{array}{l}-0.1545^{*} \\
(0.0823)\end{array}$ \\
\hline Island (dummy) & $\begin{array}{c}0.1323 \\
(0.1718)\end{array}$ & & & & & & $\begin{array}{c}0.2427 \\
{[0.1982]}\end{array}$ & $\begin{array}{c}0.3559 \\
(0.2265)\end{array}$ & \\
\hline Landlocked (dummy) & & $\begin{array}{l}-0.2687^{*} \\
(0.1585)\end{array}$ & & & & & & & \\
\hline Dependency (dummy) & & & $\begin{array}{l}0.6358^{* *} \\
(0.2505)\end{array}$ & & & & $\begin{array}{l}0.9361^{* * *} \\
{[0.2930]}\end{array}$ & $\begin{array}{l}1.1834^{*} \\
(0.6494)\end{array}$ & \\
\hline Sub-Saharan Africa (dummy) & & & & $\begin{array}{l}-0.2606^{*} \\
(0.1341)\end{array}$ & & & & & \\
\hline Latin America (dummy) & & & & $\begin{array}{c}0.1920 \\
(0.1345)\end{array}$ & & & & & \\
\hline Oil Exporter (dummy) & & & & & $\begin{array}{c}0.0960 \\
(0.1891)\end{array}$ & & & & \\
\hline $\begin{array}{l}\text { Diamonds discovered prior to } 1989 \\
\text { (dummy) }\end{array}$ & & & & & $\begin{array}{c}0.1331 \\
(0.1481)\end{array}$ & & & & \\
\hline $\begin{array}{l}\text { Energy and Mineral depletion/GNI } \\
2001\end{array}$ & & & & & & $\begin{array}{l}-0.0527 \\
(0.5376)\end{array}$ & & & \\
\hline$R^{2}$ & 0.5382 & 0.5466 & 0.5592 & 0.5736 & 0.5407 & 0.5359 & 0.5038 & 0.5304 & 0.3630 \\
\hline$n$ & 127 & 127 & 127 & 127 & 122 & 111 & 97 & 90 & 62 \\
\hline
\end{tabular}

Notes: All regressions include an intercept and controls for Neo-Europe and Latitude. The superscript ${ }^{* * *}$ denotes significant at the $1 \%$ level, ${ }^{* *}$ significant at the $5 \%$ level, significant at the $10 \%$ level. Standard errors in ( ), robust standard errors in [ ], Robust standard errors have been used when the null-hypotheses of no heteroscedasticity according to White's test could be rejected. Estimated by OLS.

a: Countries with a population less than 500'000 are excluded from the regression

b: The countries whose Rule of Law estimates standard error is in excess of 0.2 are excluded from the regression.

c: Expropriation risk is the dependent variable, taken from Acemoglu et al (2001), hence the smaller sample size. 
Figure 1: Partial Scatter Plot, Rule of Law vs. Log Area (World Sample)

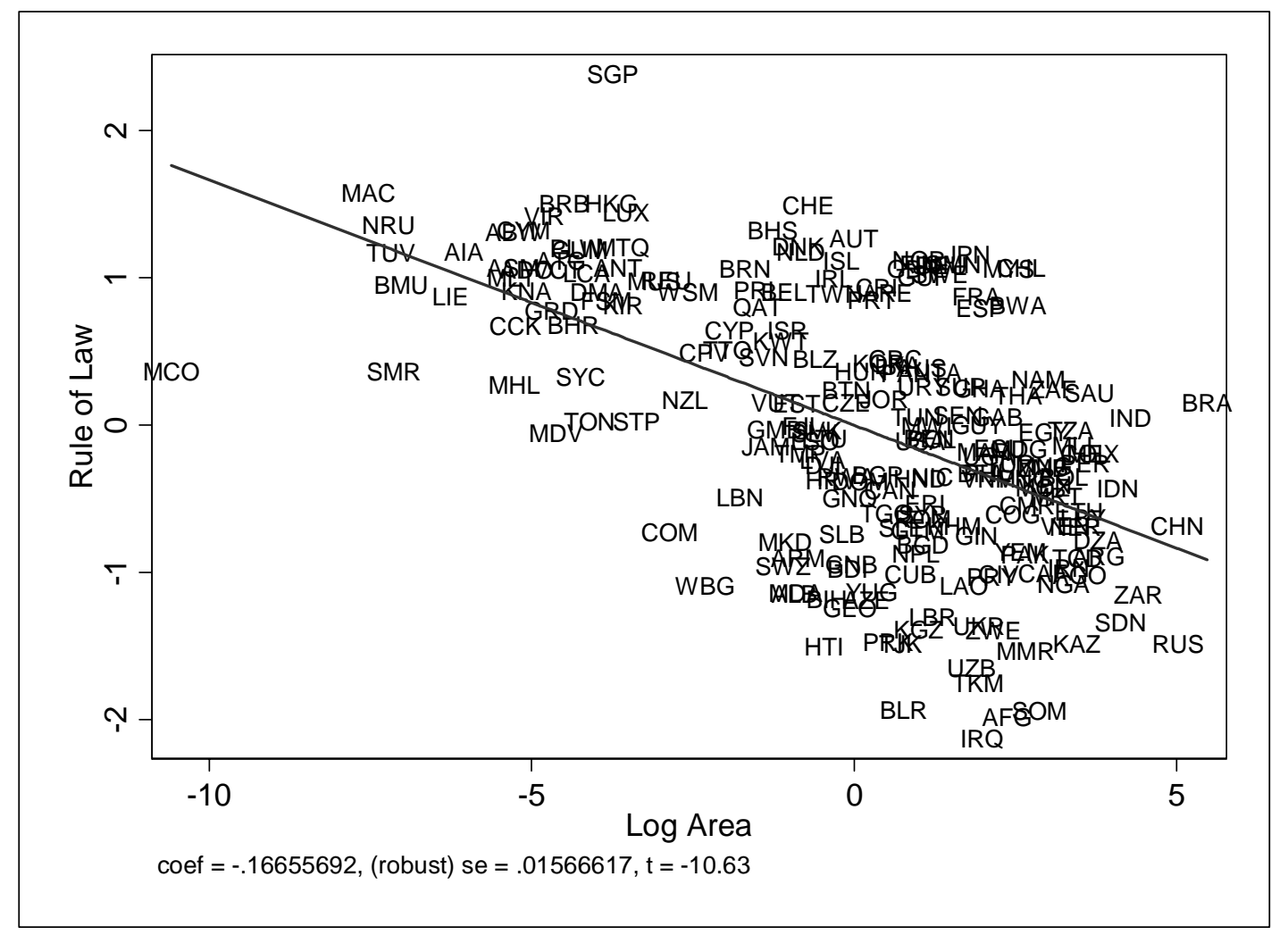

Figure 2: Illustration of distance from and centrality of the capital.

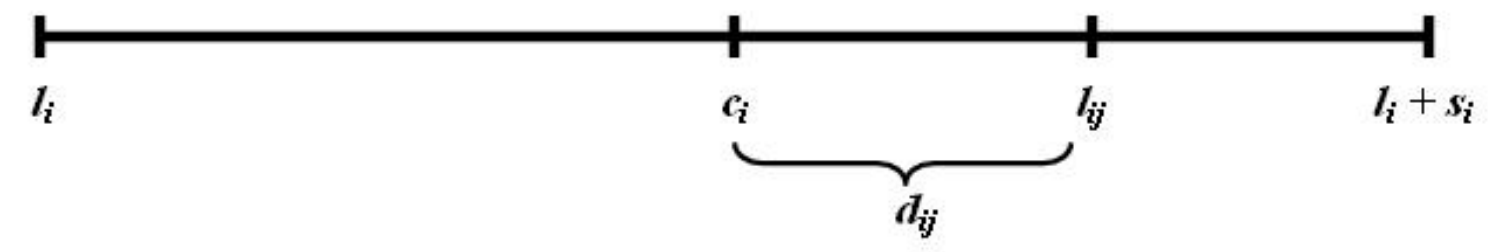


Figure 3: Partial Scatter Plot, Rule of Law vs. Log Area (Former Colony Sample)

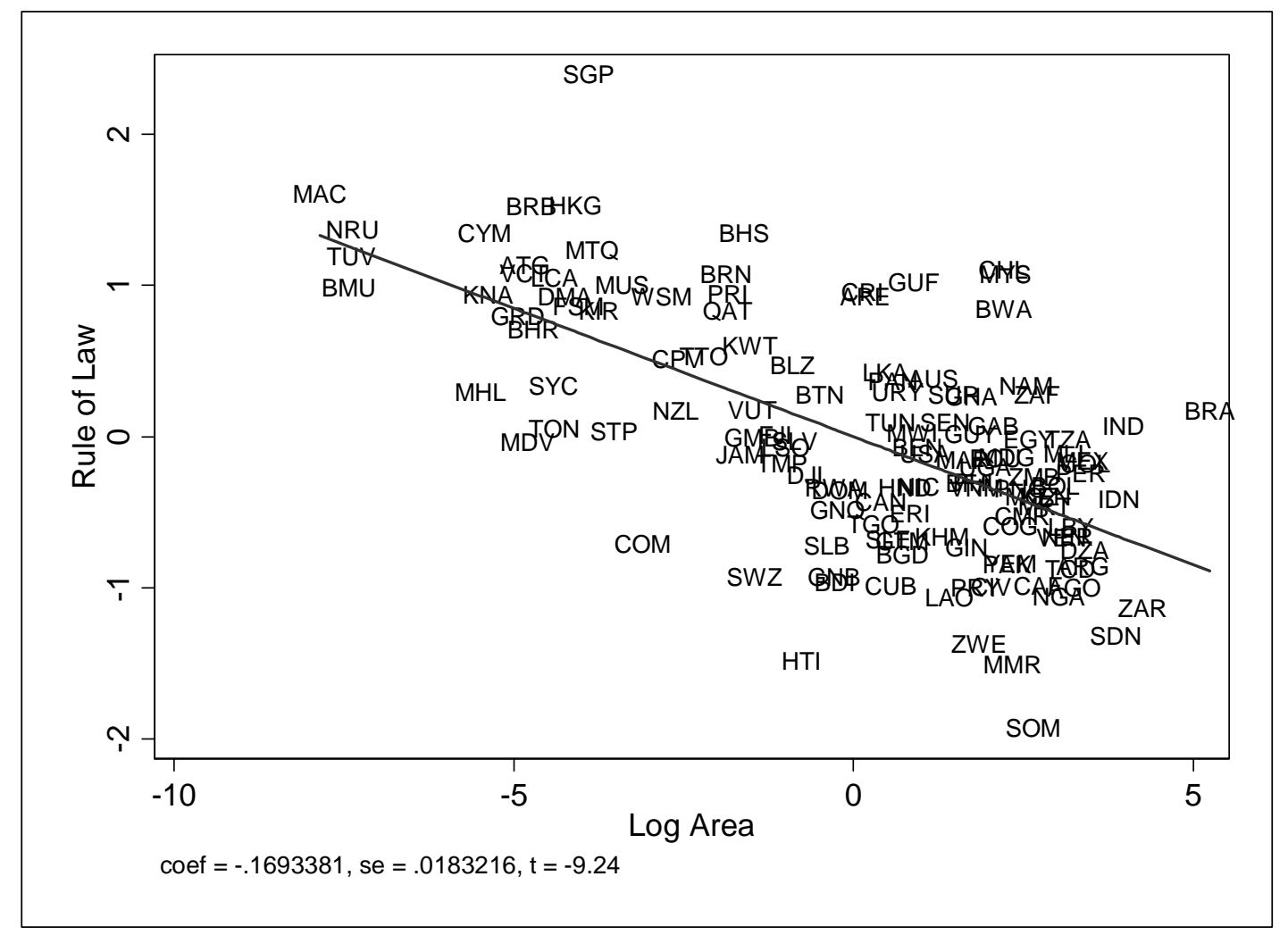


Figure 4: Illustration of Periphery Measure, Namibia and Mozambique

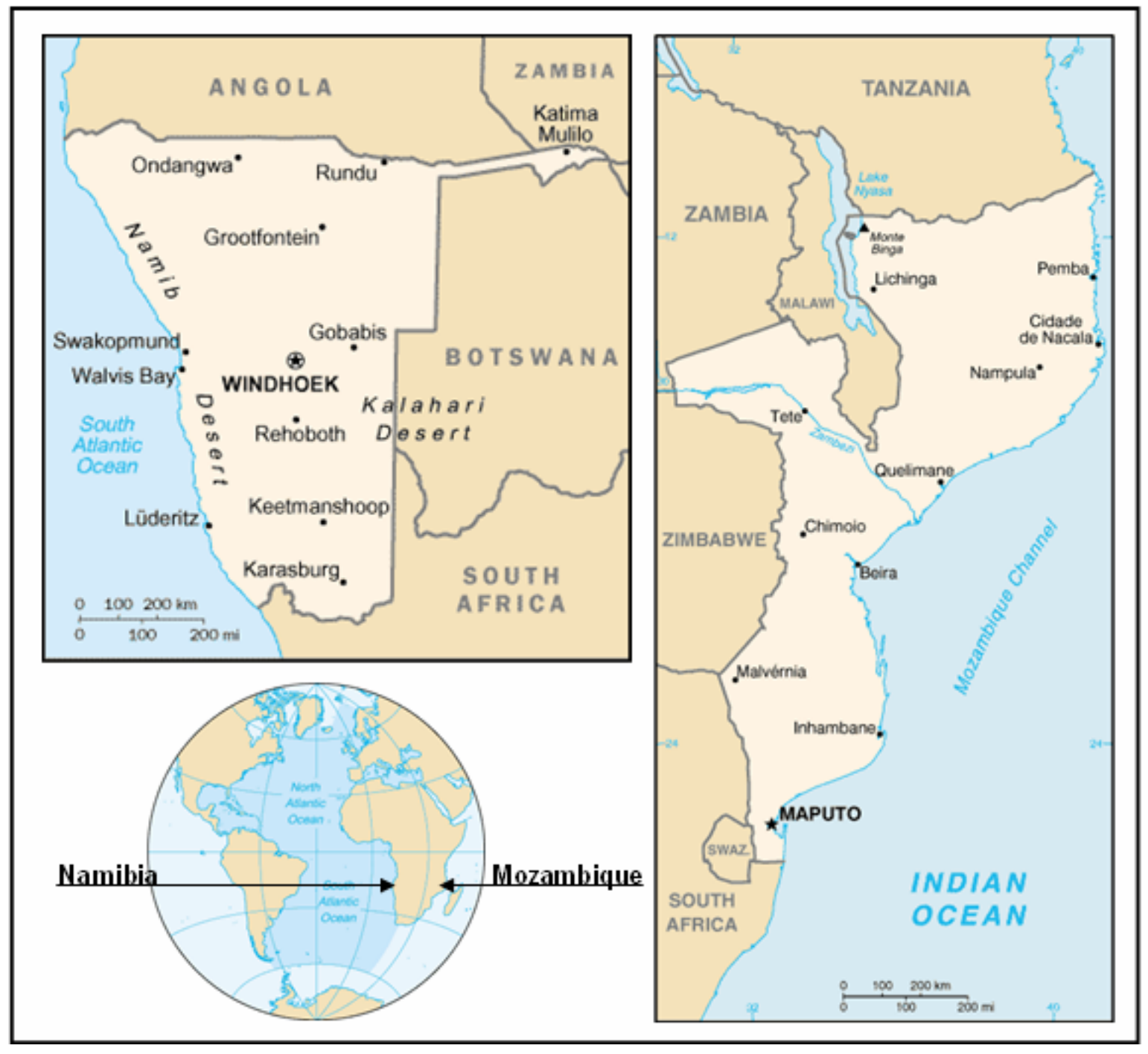

Notes: Maps retrieved from CIA World Factbook 
Summary Statistics

\begin{tabular}{lcrrrr}
\hline All the World Sample & & & & & \\
\hline Variable & Obs & \multicolumn{1}{c}{ Mean } & Std. Dev. & \multicolumn{1}{c}{ Min } & Max \\
\hline Rule of Law & 208 & 0.0000 & 1.0000 & -2.3068 & 2.0124 \\
Political Stability & 207 & 0.0000 & 1.0000 & -2.8718 & 1.7696 \\
Voice \& Accountability & 207 & 0.0000 & 1.0000 & -2.1875 & 1.5851 \\
Gov't Effectiveness & 209 & 0.0000 & 1.0000 & -2.3204 & 2.2523 \\
Regulatory Quality & 204 & 0.0000 & 1.0000 & -2.6269 & 2.0159 \\
Control of Corruption & 204 & 0.0000 & 1.0000 & -1.6488 & 2.5301 \\
Log Area & 209 & 10.8734 & 3.0395 & 0.6678 & 16.6546 \\
Neo-Europe & 209 & 0.0191 & 0.1373 & 0.0000 & 1.0000 \\
Abs Latitude & 209 & 24.6153 & 16.5380 & 0.0000 & 65.0000 \\
\hline
\end{tabular}

Former Colony Sample

\begin{tabular}{|c|c|c|c|c|c|}
\hline Variable & Obs & Mean & Std. Dev. & Min & Max \\
\hline Rule of Law & 127 & -0.2194 & 0.8876 & -2.3068 & 1.9258 \\
\hline Rule of Law se & 127 & 0.1786 & 0.0749 & 0.1135 & 0.7105 \\
\hline Rule of Law n & 127 & 9.2047 & 4.4496 & 1.0000 & 17.0000 \\
\hline Total area & 127 & 680882 & 1634000 & 21 & 9984670 \\
\hline Population & 127 & 27800000 & 101000000 & 10299 & 1050000000 \\
\hline Pop. density & 127 & 368.8476 & 1738.9860 & 1.9093 & 17765.6700 \\
\hline Open & 97 & 0.8242 & 0.4662 & 0.2363 & 2.9331 \\
\hline Log Area & 127 & 10.9877 & 3.0812 & 3.0445 & 16.1166 \\
\hline Log Population & 127 & 15.0881 & 2.3000 & 9.2398 & 20.7762 \\
\hline Log Population Density & 127 & 4.1004 & 1.6508 & 0.6467 & 9.7850 \\
\hline Log Open & 97 & -0.3360 & 0.5369 & -1.4426 & 1.0761 \\
\hline Log Distance & 120 & 4.9640 & 1.4520 & 0.9285 & 7.6325 \\
\hline Periphery & 95 & 0.8269 & 0.4434 & 0 & 2.1631 \\
\hline Ethnicity1 & 92 & 0.5522 & 0.2536 & 0.0395 & 1.0000 \\
\hline Ethnicity2 & 117 & 0.4932 & 0.2601 & 0.0000 & 0.9302 \\
\hline Religious Fractionalization & 125 & 0.4621 & 0.2427 & 0.0023 & 0.8603 \\
\hline Log Settler Mortality & 69 & 4.685 & 1.2171 & 2.1459 & 7.9862 \\
\hline Duration of Colonial Rule & 127 & 173.1890 & 126.5852 & 38.0000 & 513.0000 \\
\hline Years of Independence & 127 & 62.7638 & 57.3785 & 0.0000 & 228.0000 \\
\hline Colonized after 1850 & 127 & 0.5197 & 0.5016 & 0.0000 & 1.0000 \\
\hline Legal Origin UK & 125 & 0.4640 & 0.5007 & 0.0000 & 1.0000 \\
\hline Legal Origin France & 125 & 0.4960 & 0.5020 & 0.0000 & 1.0000 \\
\hline Legal Origin Socialist & 125 & 0.0400 & 0.1967 & 0.0000 & 1.0000 \\
\hline Island & 127 & 0.2992 & 0.4597 & 0.0000 & 1.0000 \\
\hline Landlocked & 127 & 0.1417 & 0.3502 & 0.0000 & 1.0000 \\
\hline Dependency & 127 & 0.0551 & 0.2291 & 0.0000 & 1.0000 \\
\hline Sub-Saharan Africa & 127 & 0.3465 & 0.4777 & 0.0000 & 1.0000 \\
\hline Latin America & 127 & 0.2756 & 0.4486 & 0.0000 & 1.0000 \\
\hline Oil Exporter & 122 & 0.0984 & 0.2990 & 0.0000 & 1.0000 \\
\hline Diamonds discovered $<1989$ & 122 & 0.2459 & 0.4324 & 0.0000 & 1.0000 \\
\hline Energy \& Mineral Depletion/GNI 2001 & 111 & 0.0484 & 0.1075 & 0.0000 & 0.5462 \\
\hline Expropriation Risk & 62 & 6.5173 & 1.4865 & 3.5000 & 10.0000 \\
\hline
\end{tabular}


Variable Description

\begin{tabular}{|c|c|}
\hline Rule of Law & Rule of Law, Source Kaufmann et al (2005) \\
\hline Rule of Law se & Standard Error of Rule of Law measure, Source Kaufmann et al (2005) \\
\hline Rule of Law n & Number of sources per estimate, Source Kaufmann et al (2005) \\
\hline Political Stability & Political Instability and Violence, Source Kaufmann et al (2005) \\
\hline Voice \& Accountability & Voice and Accountability, Source Kaufmann et al (2005) \\
\hline Gov't Effectiveness & Government Effectiveness, Source Kaufmann et al (2005) \\
\hline Regulatory Quality & Regulatory Quality, Source Kaufmann et al (2005) \\
\hline Control of Corruption & Control of Corruption, Source Kaufmann et al (2005) \\
\hline Neo-Europe & Dummy variable, $=1$ if Australia, Canada, New Zealand, or the USA \\
\hline Abs Latitude & Absolute latitude degree. From: CIA World Factbook 2005, \\
\hline Total area & Total area (including lakes and rivers) in sq km, Source CIA World Fac book 2005 \\
\hline Population & Total Population (2002), Source UNSTATS \\
\hline Pop. density & Total population divided by total area in sq $\mathrm{km}$ \\
\hline Log Area & Natural logarithm of total area \\
\hline Log Population & Natural logarithm of population \\
\hline Log Population Density & Natural logarithm of population density \\
\hline Open & $\begin{array}{l}\text { Open=(exports + imports)/GDP, all from } 2002 \text { in current prices local currency units. } \\
\text { Source World Development Indicators } 2004\end{array}$ \\
\hline Log Open & Natural logarithm of open \\
\hline Ethnicity1 & Ethnic Fractionalization. From Fearon (2003) \\
\hline Ethnicity2 & Ethnic Fractionalization. Covers the period1979-2001. From Alesina et al (2003) \\
\hline $\begin{array}{l}\text { Religious } \\
\text { Fractionalization }\end{array}$ & Religious Fractionalization, for 2001. From Alesina et al (2003) \\
\hline Log Settler Mortality & Natural logarithm of Settler Mortality, from Acemoglu et al (2000) \\
\hline $\begin{array}{l}\text { Duration of Colonial } \\
\text { Rule }\end{array}$ & $\begin{array}{l}\text { Duration of colonial rule. Year of independence (max 2004) minus year of } \\
\text { colonialization. Own assessment }\end{array}$ \\
\hline Years of Independence & $\begin{array}{l}\text { Years of independence since colonialization. } 2004 \text { minus year of independence. Own } \\
\text { assessment. }\end{array}$ \\
\hline Colonized after 1850 & Dummy variable. $=1$ if colonized after the year 1850. Own assessment. \\
\hline Legal Origin UK & Legal Origin British, From La Porta et al (1999) \\
\hline Legal Origin France & Legal Origin French From La Porta et al (1999) \\
\hline Legal Origin Socialist & Legal Origin Socialist, From La Porta et al (1999) \\
\hline Island & $\begin{array}{l}\text { Dummy variable. }=1 \text { if Island. An Island is defined as a country with no land boundary. } \\
\text { Based on "land boundary" from CIA World Factbook } 2005 .\end{array}$ \\
\hline Landlocked & Dummy variable. $=1$ if country is landlocked. From CIA World Factbook 2005 \\
\hline Dependency & $\begin{array}{l}\text { Dummy variable. }=1 \text { if country is not independent, not its own sovereignty. From CIA } \\
\text { World Factbook } 2005\end{array}$ \\
\hline Sub-Saharan Africa & Dummy variable. $=1$ if country is part of Sub-Saharan Africa \\
\hline Latin America & Dummy variable. $=1$ if country is part of Latin America \\
\hline Oil Exporter & $\begin{array}{l}\text { Dummy variable. }=1 \text { if oil exports }>50 \% \text { of total exports. From Lujala, Gleditsch, } \\
\text { Gilmore (2005) }\end{array}$ \\
\hline $\begin{array}{l}\text { Diamonds discovered } \\
<1989\end{array}$ & $\begin{array}{l}\text { Dummy variable. =1 if Diamonds discovered in country prior 1989. From Lujala, } \\
\text { Gleditsch, Gilmore (2005) }\end{array}$ \\
\hline $\begin{array}{l}\text { Energy \& Mineral } \\
\text { Depletion/GNI } 2001\end{array}$ & $\begin{array}{l}\text { Energy (crude oil, natural gas, and coal) and Mineral (bauxite, copper, gold, iron, lead, } \\
\text { nickel, phosphate, silver, tin, and zinc) depletion as a share of GNI 1999. From World } \\
\text { Bank data on Adjusted Net Savings. }\end{array}$ \\
\hline Expropriation Risk & Expropriation Risk, From Acemoglu et al (2001) \\
\hline
\end{tabular}




\begin{tabular}{|c|c|}
\hline Log Distance & 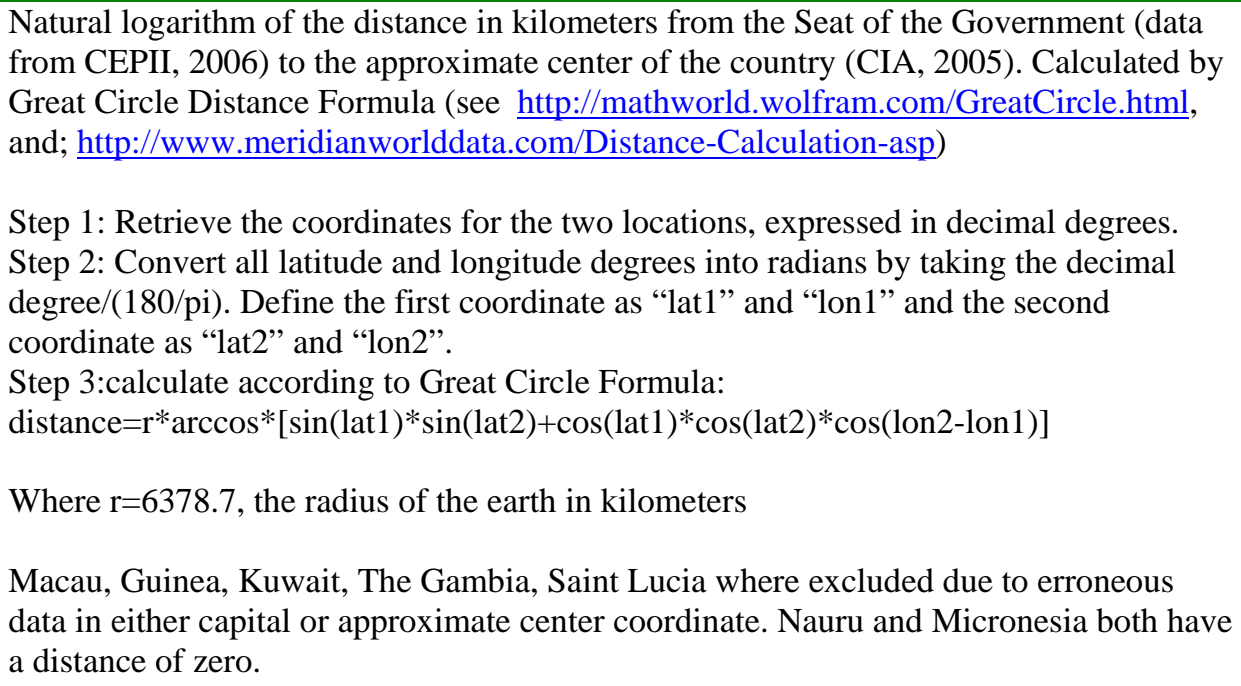 \\
\hline Periphery & $\begin{array}{l}\text { Measure of uncentrality of the capital. Periphery equals the distance from center to } \\
\text { capital (as calculated above) divided by the square root of total area divided by pi. The } \\
\text { Shape of all countries is here assumed to be described as a circle, and where (total } \\
\text { area/pi) }\end{array}$ \\
\hline
\end{tabular}

